(C) 1984 ISIJ

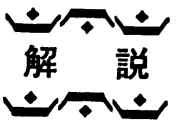

\title{
再結晶核生成場所としての変形組織
}

\author{
川崎宏 一**松尾宗 次*2
}

\section{Deformation Structures as Nucleation Sites for Recrystallization}

Kouichi Kawasaki and Munetsugu Matsuo

\section{1.はじめに}

典型的な再結晶は熱的活性化により, 塑性変形組織中 に格子歪みを解消した再結晶核が発生し，この再結晶核 の成長により変形組織が消失するといらプロセス（不連 続再結晶）を経る。（このプロセスを通らない再結晶と して連続再結晶（その場再結晶）があるがこれについて は本号に別に解説1)があり，ここでは扱わない）

再結晶核の生成は再結晶過程全体に対して支配的な役 割を果たし，結晶粒度や優先方位形成など材質特性に重 要な意味を持つ.この再結晶核は熱摇動による核生成で はなく，変形組織中にセルとして潜在しており，再結晶 方位も圧延集合組織の方位分散内に含まれると考㝋られ ている．この再結晶の萠芽は特定の条件を具備する．結 晶とくに多結晶体の圧延変形後の組織では場所的に結晶 の格子歪や方位回転状態が異なつている，このような変 形の局所不均一性の中で，蓄積エネルギーが大きく，格 子湾曲の大きい場所が，最も容易に歪みを解放して核生 成し，急速に再結晶粒へ成長できるといら考方方が一般 的である. したがつて再結晶核の供給源としての不均一 変形組織の本性の解明が再結晶現象の基本的理解につな がるはずである。

変形帯, 遷移帯, 粒界近傍などと呼ばれる不均一変形 組織は格子欠陥とくに転位分布の偏りによつて生じるも のであり, 光学顕微鏡から電子顕微鏡へと観察手段の進 歩につれてその微細構造の解析が 進展してきた. した がつて優先的再結晶核生成場所としての変形組織を分類 し，その構造と形成機構を明らかにすることが本文の第 一のテーマである．次に格子歪みの蓄積・解放とそれに 伴う転位構造の変化を回復から核化のプロセスにおいて 解明することが第二のテーマである. 現在，これらのテ 一マはまだ解明の途上であり，本文ではむしろ問題のあ りかを説明することにとどめる。 まず变形組織の分類を 行い，各歪み段階に扣いて優先核生成場所となりやすい 変形組織について述べ，さらに各場所での優先方位を概 括する. 最後に今後の展開として理論的取扱いを可能と
するための変形組織形成機構のモデルを紹介する．これ は再結晶核生成による優先方位の発生の理論的考察の基 礎をなすもので, 塑性力学モデルと転位論モデルに分け られる.

以上の諸点についての総括的な参考文献を 2)〜8) に あげるなお変形はすべて冷間とする.

\section{2. 変形組織の分類}

旧来，不均一な変形組織は固有の微細組織的特徵によ り種々の名称で呼ばれてきた，以下再結晶核生成に関連 した変形組織を形態分類して示す. 変形組織の名称はま だ統一したものはないが，ここでは主として DillamoRE によよつた. 変形帯 (deformation band) はマトリッ クス帯や遷移帯などの筋状模様の組織を指す名称として 研究者によつてまちまちに使われて拈り，むしろこのよ うな不均一組織の一般的名称となつているので本稿では 使用しない. 変形組織の模式図を Fig. 1 に示す.マト

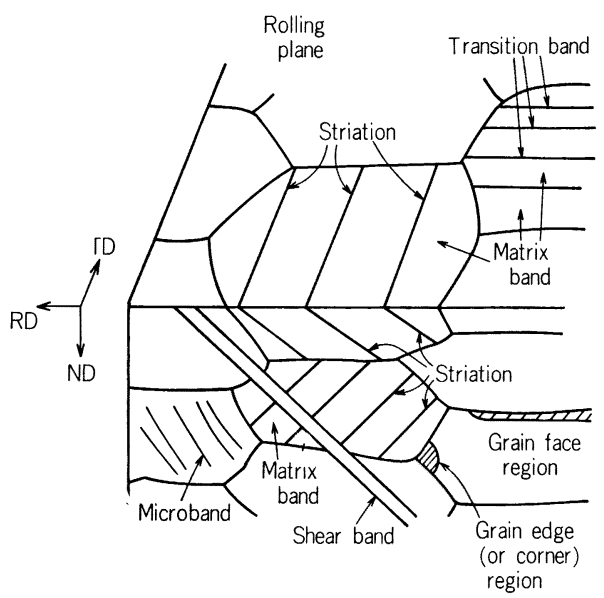

RD $\cdot$ Rolling direction, TD : Transverse direction ND : Normal direction

Fig. 1. Schematic representation of deformation structures in rolled sheet.

昭和 59 年 6 月 6 日受付 (Received June 6, 1984) （依頼解説）

* 新日本製鉄 (株) 君津技術研究部 (Kimitsu Technical Research Laboratories, Nippon Steel Corp., 1 Kimitsu Kimitsu 299-11)

*2 新日本製鉄(株)第一技術研究所 工博 (R \& D Laboratories - I, Nippon Steel Corp.) 
リックス帯 (matrix band) は, 当初 WALTER-KOCH ${ }^{10)}$ が matrix deformation band と命名したが, 最近 DoHERTY5) そ従つて matrix band と呼ばれるよらになつ た。マトリックス帯は 0.2 1 $\mu \mathrm{m}$ の等軸セルまたは压 延方向に延伸したセルよりなり結晶方位はほぼ均一であ り，主として連続再結晶の核供給源となる。

\section{1 遷移帯 (transition band)}

Photo. 111) でマトリックス帯を分離している筋状組 織が遷移帯である。電子顕微鏡観察によれば遷移帯は, Photo. 212) そ例示するように, 1〜 $3 \mu \mathrm{m}$ 幅中に鮮明な 境界の延伸セルが平行に数本〜十数本並んだ帯状構造を して物り，結晶方位は遷移帯を隔てたマトリックス帯間 の角度差 $\left(10 \sim 50^{\circ}\right)$ を各セルが平等に分担しながら連続 的に変化している ${ }^{11) 12)}$. $\mathrm{Fe}-3 \% \mathrm{Si}, \mathrm{Fe}-0.02 \% \mathrm{C}$ では $\{110\}\langle 001\rangle$ 核が発生する $\{112\}$ 面上の筋状組織（striation）が認められているが遷移帯とは異なるようであ

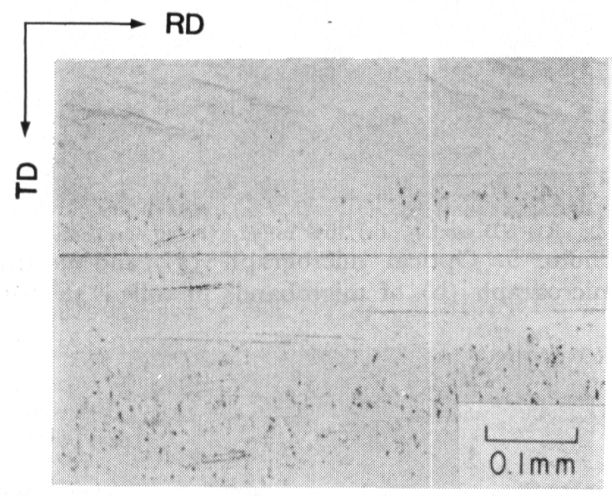

Photo. 1. Optical micrograph of matrix bands and transition bands in $80 \%$ rolled $\{001\}\langle 100\rangle$ Fe-3\% Si single crystal ${ }^{11)}$.

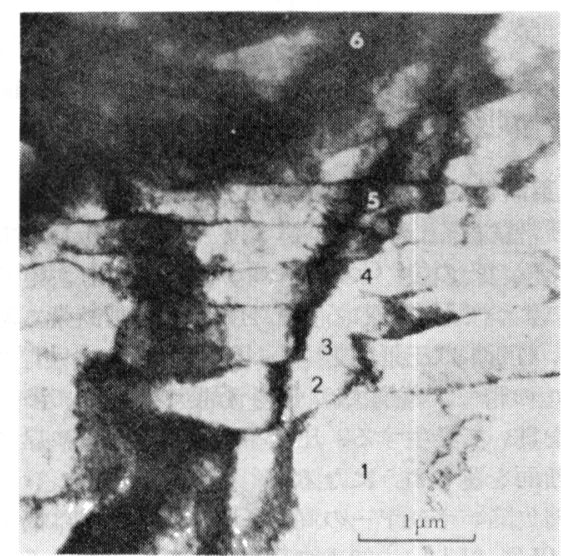

2 5 : Elongated cells in the transition band, 1, 6: Matrix bands with misorientation of $30^{\circ}$ determined from the diffraction patterns.

Photo. 2. Electron micrograph of a transition band between matrix bands in $50 \%$ rolled polycrystalline iron ${ }^{12)}$.

\section{る ${ }^{13)}$ 15). (4.1 参照)}

\section{$2 \cdot 2$ 粒界近傍（grain boundary region)}

粒界近傍では粒内とは変形挙動が異なることを最初に BOAS-HARGREAVES が示した ${ }^{16)}$. 阿部らによる純鉄の粒 界近傍変形組織の観察例を Photo. 3 飞寺すが, 粒界 の片側が濃く腐食されることが多く, そこは硬度も高 い17). Photo. 4 の LEFFERS による銅の電子顕微鏡観察 例でも粒界の片側に延伸セルの束が存在し, 粒界近傍の セル間の方位差が重畳されて大きな格子湾曲を生じてい ることが認められる18)

MORRIS は多結晶鉄圧延 $(70 \%)$ 板の電子顕微鏡観察 から，観察した粒界の約 40\% 飞 Photo. 4 と同様の組 織を認め, この延伸セルの束は低 $M$ 值 (5.1 参照) 側 の結晶粒のみに生じるとしている。これは粒界での応力 の連続性のため軟い低 $M$ 值粒の粒界近傍が優先的に加 工硬化するので，このような延伸セルの束ができるとし ている19)。また，これらのセルは先の小傾角境界で粒内 と隣接粒との方位差を調整して扣り, 遷移帯と類似の構 造を持つものと考光られる。

JONES は $\mathrm{Al}$ の 10\% 圧延後の変形組織の電子顕微鏡 観察を行いこのような低歪みでも粒界三重点近傍ではセ 儿組織の微細化がみられることを示した ${ }^{20)}$ 。一般に粒界 のエッジ，コーナー (Fig. 1 参照) では粒間の変形歪み の連続性を保つため, 大きな局所雨みが生じ, 粒界面よ り早期飞変形組織形成が進むと考光られる.

マトリックスよりも硬い第二相粒子の周囲にも粒界近 傍と類似の変形組織が形成されると考学られる。ただし 介在物界面は粒界より歪みの連続性が低くセル形態も異
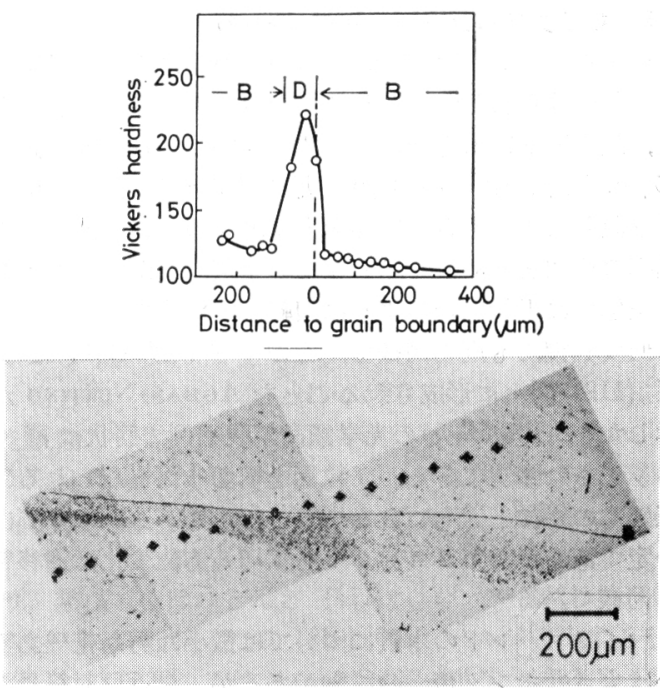

B : Brightly etched region, D : Darkly etched region.

Photo. 3. Optical micrograph and hardness distribution of the grain boundary region in $70 \%$ rolled coarse-grained pure iron ${ }^{17}$ ). 

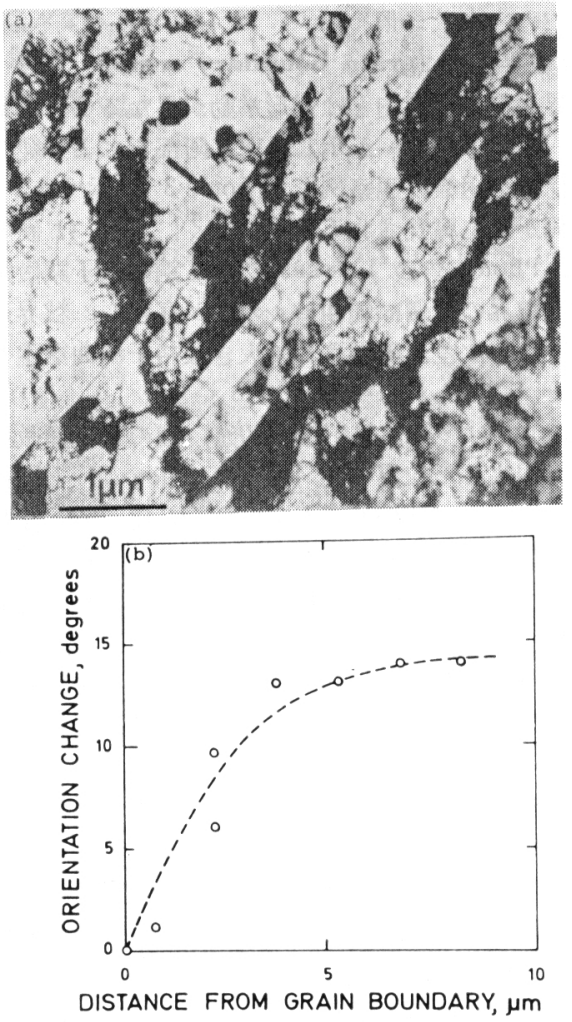

Photo. 4. Electron micrograph and orientation change at grain boundary region in $50 \%$ rolled copper ${ }^{18)}$.

なると思われる。

\section{$2 \cdot 3$ マイクロバンド (micro band)}

マイクロバンドは AHLBORN-SAUER によつて見出さ れ，名づけられた 之, 最大剪断応力方向に近いすべり面 $\{111\}$ 上に, 長さ $40 \mu \mathrm{m}$ 以下, 幅 $20 \sim 30 \mu \mathrm{m}$, 厚さ $0.2 \sim 0.3 \mu \mathrm{m}$ の単位 で分散してできる鋭い境界をもつセルの一種である。圧 延率の増加と共に数を増しながら集積し，かつバンド壁 が圧延面に平行になるように回転していく22).

低炭素鋼でも銅と同样で，そのすべり面 $\{110\}$ また は $\{112\}$ 面上に形成されることを AGHAN-NuTting が 示した ${ }^{23)}$. Photo. 5 の光学顕微鏡観察例で筋状に薄く エッチされ識別できるが，粒界を横切る例もみられる. 圧延率の増加とともに数を増し, 幅が拡がるがセル幅は 一定である、マイクロバンドを横切る方位変化は遷移带 と同様である ${ }^{23)}$.

マイクロパンドの本質については微小な剪断帯22)ある いは大きなキンク帯との説9) があるが, 最近反対符号の 平行な集積転位列間の応力が二次すべりによつて解放さ れ tilt 壁が形成されて生じるとの見解が JACKSONKUHLMANN·WILSDORF によつて示された24).

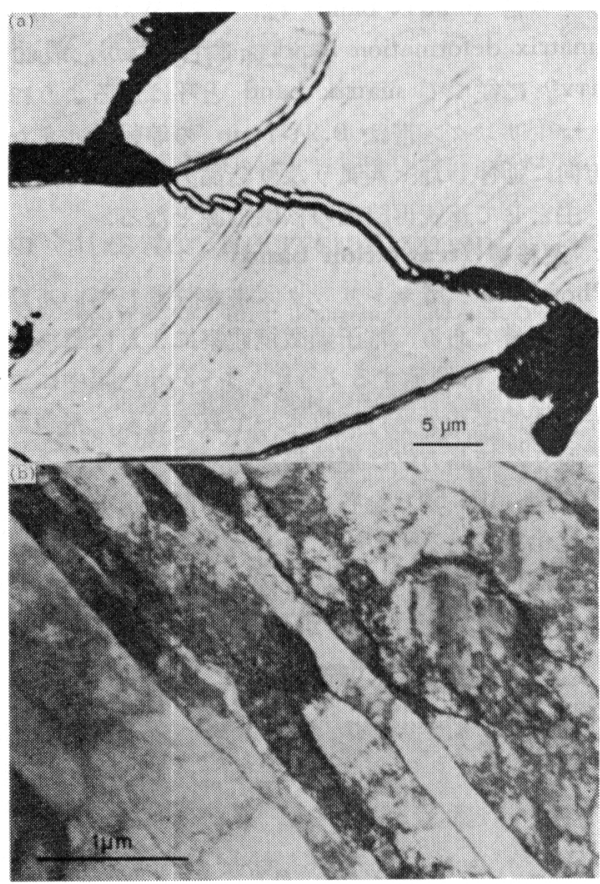

RD-ND section, (a) $10 \%$ rolled, (b) $40 \%$ rolled. Photo. 5. Optical micrograph (a) and electron micrograph (b) of microbands in rolled steel ${ }^{23)}$.

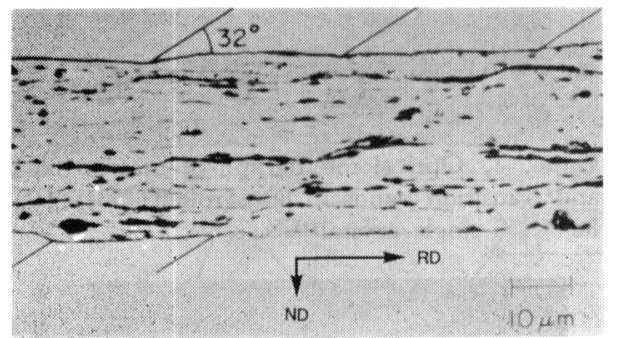

Photo. 6. Optical micrograph of shear bands in $99 \%$ rolled Al-killed steel ${ }^{27}$ ).

\section{$2 \cdot 4$ 剪断帯 (shear band)}

剪断帯は古く ADCOCK により $\mathrm{Cu}-\mathrm{Ni}$ 圧延板で観察 された25)。午の後 COOK-RICHARDS はこれが単純剪断 変形によつて形成されることを確認し, 剪断带と命名し た ${ }^{26)}$. 剪断帯は圧延面と $20 \sim 40^{\circ}$ の角度をなす厚さ 1 $10 \mu \mathrm{m}$ の帯で, 黄銅では $40 \%$ 程度の圧延率で多くの結 晶粒を貫いて発生する．圧延率の増加とともに厚さを増 し全断面を覆うようになる。

積層欠陥エネルギーの高い $\mathrm{Cu}, \mathrm{Al}, \mathrm{Fe}$ では高圧延率 (70 95\% 以上) で初めて発生する. Photo. 6 の A1 キルド鋼を 99\% 圧延した際にできた剪断帯の例では, 巨視的な剪断变形が板厚を貫通している27)。また Nb 添 加鋼を $80 \%$ 圧延した場合の電子顕微鏡観察を Photo. 7 に示す。微細に分散した $\mathrm{Nb}(\mathrm{CN})$ のためにより低雪み 


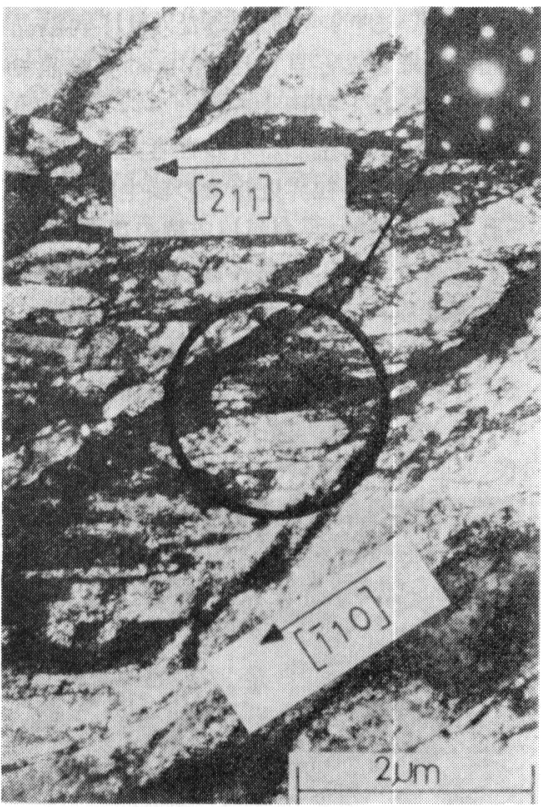

RD-ND section.

Photo. 7. Electron micrograph of shear band in $80 \%$ rolled $0.3 \% \mathrm{Nb}-$ steel $^{28)}$.

で剪断帯が発生したと考光られる. 剪断帯内のセル構造 は延伸セルと等軸セルの混在と夕られている ${ }^{28)}$.

剪断帯は塑性不安定にもとつく不均一変形により生じ る。積層欠陥エネルギーが低く低歪みですべり変形が困 難となる黄銅などでは低圧下率で, 積層欠陷エネルギー の高い金属では圧延集合組織が極度に発達してすべり変 形よりも剪断変形の方がェネルギー的に有利な状態とな つて出現する.な扣剪断帯は周囲のマトリックスに対し 独立に生じ，他の変形組織には影響を与兄ない。

\section{3. 優先核生成場所}

\section{1 低，中歪み}

低，中雪及(压延率 $50 \%$ 以下) では乞の場再結晶も重 要な再結晶形態であるが，核生成を伴う再結晶に执いて は核生成場所は多様なるのとなる。主として粒界近傍, 遷移帯などが選択される. 塑性加工前の粒径, 粒方位に よつてこれらの変形組織の発達の程度が異なる．粒間の 相互作用も様々で粒界近傍の变形組織の発達の程度も広 範囲にわたり，核生成は粒のコーナー，エッジ，面の各 箇所から生じる. 変形組織の中で小さなセルサイズ, 大 きなセル間角度, 隣接七几間の大きなサイズ差およびセ ルの束による大さな格子湾曲といら諸条件を満たす場所 が核生成位置として優先する，剪断帯は黄銅などを除き 低, 中歪久では核発生しないので重要度は低い。

\section{2 高歪み}

高歪み（圧延率 $50 \%$ 以上）では積層欠陥エネルギー
の低い合金は剪断帯が肥大化して大部分を占めるように なり，剪断帯での核生成が主要なものとなる。これに対 乙積層欠陥ェネルギーの高い鉄, 銅, アルミニウムなど では剪断带の発生体積は小さく重要度は低く, やはり遷 移帯や粒界近傍などでの核生成が主体となる。粒間の相 互作用では層状になつた旧粒界面での整合が主となり, 新しい格子湾曲の発生は減少する, 低, 中歪みで形成さ れた粒界近傍や遷移帯などでの格子湾曲がさらに主要な 方位分散につながる鋭い遷移域一発達していくものと考 えられる，高歪みでは格子湾曲はますます大きくなり， 変形組織の種類を問わず一定のレベルに収束してくると 考えられる。

\section{4. 優先方位の発生}

\section{$4 \cdot 1$ 遷移帯}

遷移帯は小さいセルの密な連なりから成り，大きな格 子湾曲を持つている。すなわら蓄積エネルギーが高くか つ高角境界を形成しやすく, さらにマトリックス帯のセ ルとの間に大きな蓄積エネルギー差を有するといら核生 成に好適な条件を備学ている，遷移帯はその方位の安定 度により各々核生成のための最適の丕みレベルがあり, それ以上では歪みの増大とともに消隇していくので，極 度に大きな歪みでは核生成しなくなると考学られる，遷 移帯の存在比率は必ずしも大きくないため十分な数の核 が生じる場合のみ優先方位となりらる。また核はマトリ ックス帯と大きな方位差をなすため再結晶前後の結晶方 位変化が大きい. WALTER-KocH は $\{001\}\langle 100\rangle \mathrm{Fe}-$ $3 \% \mathrm{Si}$ 単結晶の圧延後の再結晶核発生を観察し遷移帯の 端のマトリックス帯と接する $\{001\}\langle 410\rangle$ などのサブグ レインから生じるケースが多いと述べている10). 遷移带 学構成するセルは不安定方位を中心に $\pm 10 \sim 20^{\circ}$ とい ら大きな方位分散を有して扣り, 核化するセルの方位に よつて優先方位は大きく左右される. $\mathrm{HU}^{11)}$ および田岡 ら ${ }^{13)}$ とよれば初方位 $\{001\}\langle 100\rangle$ などの $\mathrm{Fe}-3 \% \mathrm{Si}$ 単 結晶を圧延した際に生じる遷移帯からは $\{311\}\langle 112\rangle$ に 近い再結晶方位が得られている. この理由は必ずしも明 らかではないが, 遷移帯の方位分散の中に含まれている ものを考学られる。

初方位 $\{111\}\langle 112\rangle \sim\{110\}\langle 001\rangle$ の $\mathrm{Fe}-3 \% \mathrm{Si}$ 単結晶 を圧延して生じる $\{112\}$ 面と平行な筋状組織 (striation) からは Photo. 8 に示すように $\{110\}\langle 001\rangle$ 方位が核生 成する13)14). 古林は幅約 $1 \mu \mathrm{m}$ のこの筋状組織はPhoto. 9 に示すように約 $0.2 \mu \mathrm{m}$ の微細なセルから成つて拉 り, 結晶方位は汪とんど $\{111\}\langle 112\rangle$ で一部 $\{110\}\langle 001\rangle$ を含んでいるが，この $\{110\}\langle 001\rangle$ セルが核化すると結 論している14). これらのセルは連続的方位変化を示さ ず，圧延面と $20^{\circ}$ をなす $\{211\}$ 面上に生成して特り， マイクロバンドまたは剪断帯と一部共通した特徴を持 つ.このような笳状組織とよばれている組織については 
今後の見直しが必要と考学られる。

\section{2 粒界近傍}

鉄牤よび鋼の粒界近傍の変形組織から発生する再結晶 優先方位についての研究例をまとめてみる.

DUNN は純鉄の核の方位分散の $1 / 3$ は $\{100\}$ から $25^{\circ}$ 以内にあることを示した ${ }^{29)}$. MORRIS は 70\% 圧延した 鉄について核は $\{100\} \sim\{411\}$ の範囲に含まれると述べ ている ${ }^{19)}$. 阿部らは純鉄粗大結晶では $\{111\}$ 粒がほとん どを占めることを明らかにしている17)。稲垣は再結晶率 $23 \%$ Al キルド鋼では 138 個の再結晶粒中 63 個が 粒界近傍に核生成した $\{111\}$ 粒であることを確認してい る30). MAtsuo らは70\% 圧延した純鉄に打いてPhoto. 10 に示すよらに圧延後 $\{111\}\langle 112\rangle$ 方位の粒では粒内に $\{110\}\langle 001\rangle$, 粒界近傍に $\{111\}\langle 110\rangle$ が核生成すること

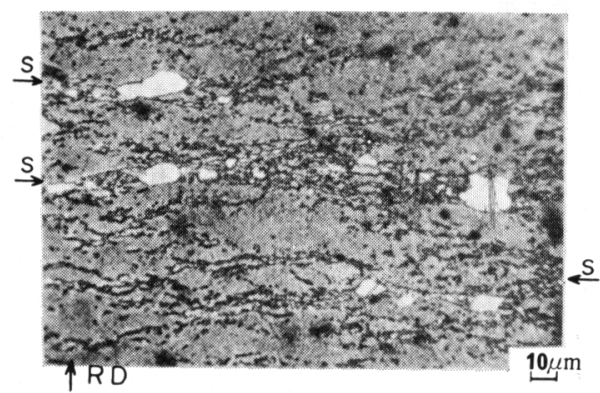

$73 \%$ rolled and $600^{\circ} \mathrm{C} \times 8 \mathrm{~min}$. annealed, $\mathrm{S}:$ Striations on $\{211\}$. Photo. 8. Optical micrograph of $\{110\}\langle 001\rangle$ nuclei generated in striations in (111) [21̄1] $\mathrm{Fe}-3 \% \mathrm{Si}$ single crystal ${ }^{14}$ ).
を明らかにしている ${ }^{31)}$ 。このような $\{111\}$ 再結晶集合組 織は単結晶では汪とんど見られず, かつ多結晶では冷延

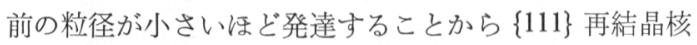
は粒界近傍に優先的に生じるるのと考学られる.

以上まとめてみると粒界近傍での核生成にも方位選択 性がみられるが優先的に $\{111\}$ 方位の再結晶核を供給 するものと考劣てよいと思われる．その機構はたと学ば 次のように考光られている ${ }^{30)}$. 粼接する結晶粒の粒界近 傍が圧延変形時に同一の共通方位に向かつて結晶回転を 起こせば, 粒界に特ける応力, 歪みの連続条件をともに

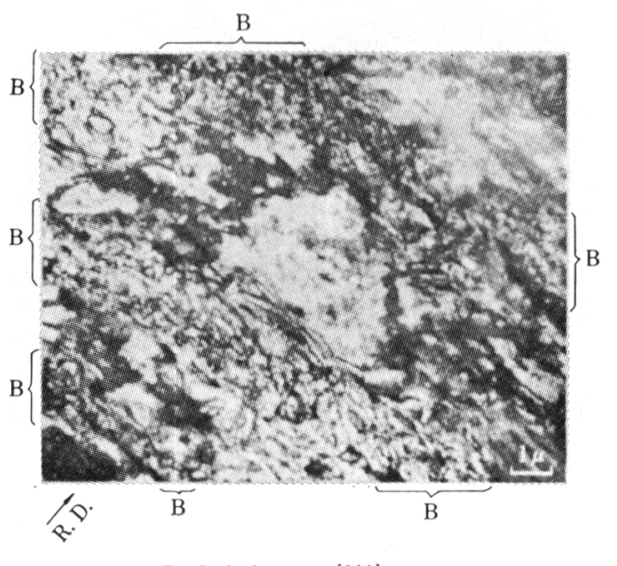

B : Striations on $\{211\}$.

Photo. 9. Electron micrograph of typical struc-

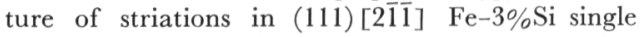
crystal rolled $83 \%{ }^{14)}$.

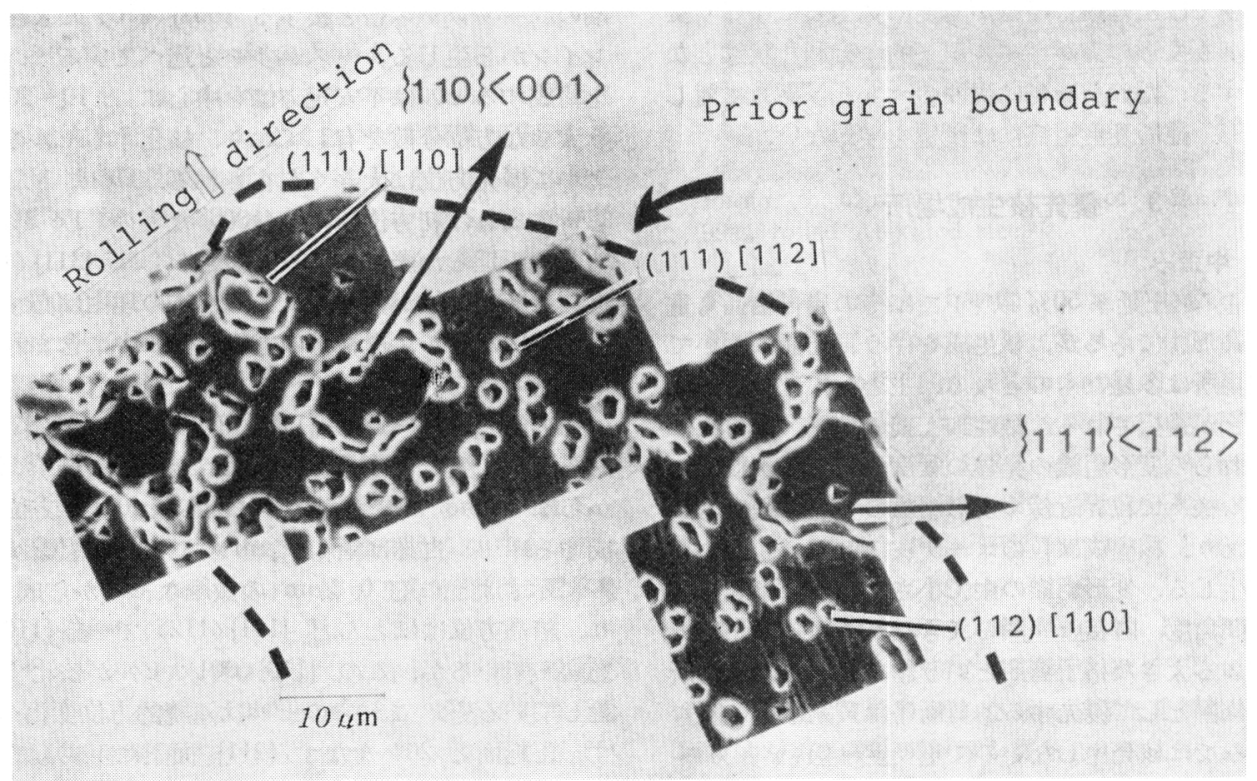

Photo. 10. Optical micrograph of micro-facet etch figure at the early stage of recrystallization in a $70 \%$ rolled pure iron ${ }^{31}$. 
満足できるので, このような回転が促進される. 圧延に よる結晶回転の到達方位の一つである $\{111\}\langle 110\rangle$ 方位 に向から粒界近傍は歪み蓄積が大きく優先核生成の要件 が備えられる。

ただし析出物などが粒界に存在してこのような連続性 が保たれ難い場合には方位選択性はなくなる，たとえば 連続焼なまし用素材の高温巻取り処理の効果の一つとし て, 炭化物の凝集により, 粒界炭化物が少なくなる 結 果, 粒界に打ける連続性が保たれやすくなつていること があるものと考えられる32).

\section{3 その他}

剪断帯は周囲のマトリックス帯とほほ類似の方位を有 している33). セルはマトリックス帯よりる小さくよく発 達しているが, 場所的に不均一となつている. 剪断帯は 微細なセル構造により, 大きな蓄積エネルギーを有し， マトリックス帯よりも優先して核発生をもたらすが, 剪 断帯内部の不均一性のためその優先方位は十分明らかと なつていない，鋼の再結晶集合組織は剪断帯の形成によ り $\{111\}$ が減じ $\{110\}\langle 001\rangle$ が増加するようである27).

々トリックス帯は再結晶過程では主として粒成長の素 地となる. しかし回復抑制効果の小さい急速加熱では蓄 積エネルギーの低い变形組織でも核生成が可能となると 考学られ，マトリックス帯からの核生成も考慮する必要 があろら.なかでも $\{111\}$ のマトリックス帯は比較的セ ルサイズも小さく核生成が期待できる.

\section{5. 優先方位発生のモデル}

\section{$5 \cdot 1$ 塑性力学モテル}

多結晶金属の圧延集合組織形成理論として TAYLOR の理論 ${ }^{34)}$ にもとづき歪みの均一性と平面歪み变形を前提 とした解析が最も成功を特さめている. Taylor モデル ではすべての粒は全体の形状変化之同一の均一な歪みを 生ずるように数個のすべり系が同時に働き，すべり系の 選択は最小仕事の原理にのつとると仮定している.
この理論にペンシルすべりの近似を取り入れ加藤らは 鉄の安定および不安定方位を Table 1 のように明らか

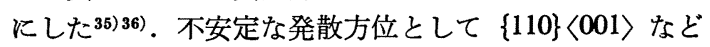
を示したが，これらの方位は遷移帯の中心方位となるこ とが期待される. $\{110\}\langle 001\rangle$ 方位近傍の発散のようす を Fig. 2 に示す36). また TAYLOR の方位因子 $M$ 值 $=\Sigma d \gamma i / d \varepsilon \quad(d \gamma i$ : 活動すべり系上での剪断歪み, $d \varepsilon:$ 主歪み増分）を計算し高 $M$ 値は高い蓄積エネルギーと対 応すると考兄, 高 $M$ 值方位の $\left\{\begin{array}{llll}11 & 11 & 8\end{array}\right\}\langle 4 \quad 411\rangle,\{111\}$ 〈110〉などが粒界近傍またはマトリックスから核生成す ることを示唆した ${ }^{35) 37) . ~}$

また秋末は圧延中に転位が何らかの理由によりそのす ベりを阻止された際に生じるねじれ領域の回転方向を求 め, その発散方位として再結晶方位を考えた ${ }^{38)}$.

\section{$5 \cdot 2$ 転位論モデル}

変形組織中では再結晶に先立つ変形および回復過程に 扣いて長範囲の応力場を解消しつつ転位の再配列が進ん でいく，再配列した転位は網状構造を形成して副境界を 作り, この境界の連なりによつて方位回転が生じる. 従 がつて再結晶粒の方位, 核生成の速度などを支配するも のはそこでできた転位網のつくる副境界の性質, 両側の 方位差, 回転軸などと考えられる. このような安定な転 位網の条件は FRANK の式 ${ }^{39}$ によつて求められる.

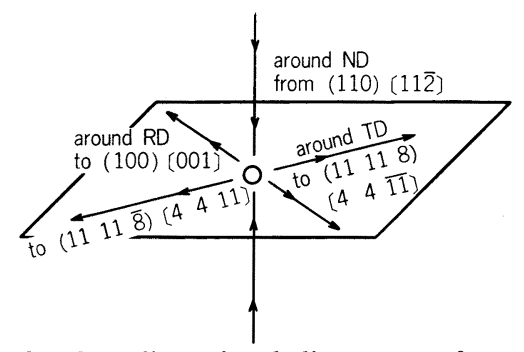

Fig. 2. Two dimensional divergence of crystal rotation near $\{110\}\langle 001\rangle$ orientation during rolling of iron ${ }^{37}$.

Table 1. Stable and divergent orientations during rolling of iron ${ }^{36)}$.

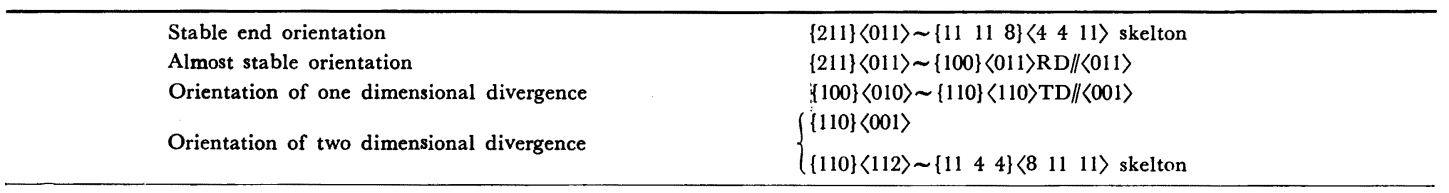

Table 2. Typical stable networks formed on a slip plane with dislocation gliding on another slip plane in iron ${ }^{40)}$.

\begin{tabular}{|c|c|c|c|c|c|c|c|}
\hline & $\begin{array}{l}\text { Planc of network or } \\
\text { first slip planc, direction } \\
\text { of dislocations and their } \\
\text { Burgers vector }\end{array}$ & $\begin{array}{l}\text { Second slip planc, } \\
\text { direction of dislocations, } \\
\text { and their Burgers vector }\end{array}$ & $\begin{array}{l}\text { Ratio of spacings } \\
\text { of the two sets of } \\
\text { dislocations } h_{1} / h_{2}\end{array}$ & $\begin{array}{l}\text { Axis } \\
\text { of tilt }\end{array}$ & $\begin{array}{l}\text { Angle } \\
\text { of tilt }\end{array}$ & $\begin{array}{l}\text { Angle } \\
\text { of twist }\end{array}$ & $\begin{array}{l}\text { Overall } \\
\text { rotation } \\
\text { axis }\end{array}$ \\
\hline 1 & $(110),[1 \overline{1} 0],[1 \overline{1} \overline{1}]$ & $(\overline{3} 12),[112],[111]$ & $\sqrt{3}$ & {$[1 \overline{1} 2]$} & $\sqrt{2} a / 2 h_{2}$ & $\sqrt{2} a / 2 h_{1}$ & [0ㅍ1] \\
\hline 2 & $(112),[312],[11 \overline{1}]$ & $(110),[1 \overline{1} 0],[1 \overline{1} 1]$ & $3 / \sqrt{7}$ & {$[1 \overline{1} 0]$} & $\sqrt{6} a / 6 h_{2}$ & $\sqrt{2} a / 2 h_{2}$ & [011] \\
\hline 03 & $(112),[1 \overline{1} 0],[11 \overline{1}]$ & $(11 \overline{2}),[1 \overline{1} 0],[\overline{1} \overline{1} \overline{1}]$ & 3 & {$[1 \overline{1} 0]$} & $\sqrt{6} a / 3 h_{2}$ & o & [11̄0] \\
\hline 4 & $(112),[37 \overline{5}],[11 \overline{1}]$ & $(\overline{3} 21),[375],[\overline{1} 1 \overline{1}]$ & 3 & {$[37 \overline{5}]$} & $\sqrt{6} a / 3 h_{2}$ & 0 & {$[37 \overline{5}]$} \\
\hline
\end{tabular}


LI はこの FRANK の式を用いて特定のすべり面上の 一次すべりに対する二次すべりの作用によつて形成され る転位境界を解析した ${ }^{40)}$. Table 2 亿鉄についての計算 の代表例を示す. $\{123\}$ 面上には安定な転位網は形成さ れず, $\{110\}$ 面上が 4 例， $\{112\}$ 面上が 14 例存在する. 計 18 例中 tilt 壁が 12 例を占め, Table 2 で○印をつ けたケースは [110] を回転軸とした $\{110\}\langle 001\rangle$ と $\{111\}$ $\langle 112\rangle$ 間の刃状転位境界飞該当し， $\{110\}\langle 001\rangle$ 方位の 鉄単結晶が圧延後 $\{111\}\langle 112\rangle$ 方位組織となり, 再結晶 すると $\{110\}\langle 001\rangle$ 方位にもどる場合の変形組織構造に 対応する. 著者らは $\{110\}\langle 001\rangle$ 方位再結晶粒の形成の 特異性を刃状転位からなる tilt 境界としての特徵をると 飞説明している41).すなわち $\{110\}\langle 001\rangle$ 方位は冷延前 の結晶粒径が大きく，また圧延中に固溶炭素との相互作 用の大きいときに再結晶方位として優先する.これらの 条件は圧延時に他の二次すべり系の活動を抑制して, 刃 状転位が集積した tilt 壁の形成による上記回転の発達に 有利に作用する。またこのような tilt 壁は微細析出物な ぞによる転位上昇運動の抑止効果を受けやすい，したが つて例党ば $\mathrm{Al}$ キルド鋼の箱焼鈍中にこの方位が選択的 に核生成を抑制され，\{111\}〈110〉再結晶方位の発達を 促すことも上述した特徵から理解できる.

最近 KuHLMANN.WILSDORF-Aernoudt は Frank の 式の図式解法42)を使用し鉄の $\{001\}\langle 100\rangle$ 単結晶を圧延 した際に形成される遷移帯中のセ儿壁の転位構造を解析 した. その結果 $\{110\}\langle 111\rangle$ すべり系中の 4 個の活動す ベり系と属するらせん転位の反応飞より, tilt 壁が (010) tilt 軸が [001] の刃状転位から成るセ儿壁が形成され ることを示した. Fig. 3 には遷移帯の 構 造の模式図を 示す43).このように転位構造モデルから導出された遷移 帯中のセル方位の変化は観察例 10) 12) 13) 44) とよく対応して いるといえる.

\section{6. ま め}

再結晶核生成場所としての变形組織の研究は次の $3 つ$ の段階に分れる.

第一段階は光学顕微鏡レベルでの分類である. 筋状組 織，粒界近傍，剪断帯などの認識がなされ，それらの場 所は再結晶核発生の優先場所としての役割を認められて いる.

第二段階は主として再結晶による優先方位の発達機構 の解明を目的とし, 電子顕微鏡によるセル構造, 七ル間 方位差, 格子湾曲の研究による微細構造の特徵づけの精 緻化である. 遷移帯, マイクロバンドをはじめ粒界近 傍, 剪断带, マトリックス帯について分類が進んで和 り，高度な実証的解明を目指している。

第三段階はモデルによる変形組織の構造および格子湾 曲の理論的解明である. 塑性力学モデルは完成度が 高 く, 転位論モデルは発達しつつある.

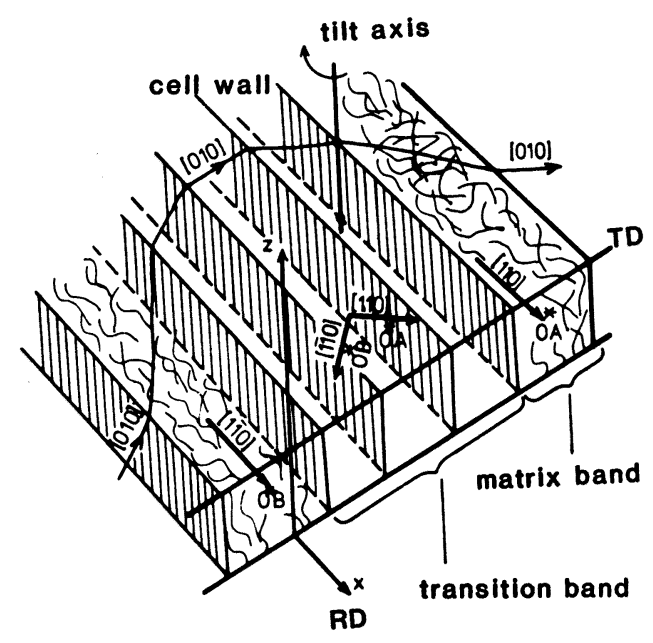

Fig. 3. A model of deformation structure in a rolled $\{001\}\langle 100\rangle$ iron single crystal ${ }^{43}$.

現状を概観すると第二段階の実証的解明はかなり進ん だがままだ分とは言えない，例壳ば遷移帯構造はほぼ 解明されているが，筋状組織，マイクロバンド，粒界近 傍，剪断帯のセル構造はまだ部分的に明らかになつてい るだけで全容を明らかにするための今後の研究が望をれ る.

第三段階ではまず塑性力学モデルが変形拘束下の結晶 回転の解明で成功を収めている，また，転位論モデルも $\{001\}\langle 100\rangle$ 単結晶の遷移帯構造の解析に有効であつた. さらにセル壁の構造解明に基づいて格子湾曲や蓄積エネ ルギーの計算が可能な点に特徵があり今後大いに期待さ れる．転位論モデルでもミクロ的拘束下の変形での活動 すべり系の決定（すなわち転位の数と種類）などに塑性 力学モデルの助けを借りる必要があろう。また実現可能 な転位構造の基準は最小エネルギーの転位網であるが， その評価基準も大きく結果を左右するので観察例との対 比が必要であろう. 塑性力学モデルによる变形集合組織 の形成に関しては電算機によるシミュレーションが成功 しているので, さらにこれを転位構造モデルまで拡大適 用できる日も近いであろう。

さら飞変形組織の転位構造の解明と平行し, 再結晶核 方位, 核生成速度の解明を目的としてセルのサブグレイ ン化拉よび核化のプロセスの実証的, 理論的研究の進展 を期待したい。

\section{交献}

1) 古林英一: 鉄と鋼, 70 (1984), p. 1816

2) 長嶋晋一編著: 集合組織 (1984), p. 144 [丸善]

3 ) 松尾宗次：鉄と銅，67 (1981), p. 1439

$4 ）$ 集合組織（日本金属学会セミナー）（1981）[日本 金属学会]

5) Recrystallization of Metallic Materials, ed. by $F$. HAEssner (1978) [Dr. Riederer Verlag]

6) W. B. Hutchinson: Met. Sci. J., 8 (1974), 
p. 185

7) I. L. Dillamore: Metals Forum, 1 (1978), p. 136

8 ) Proc. 6th Int. Conf. on Textures of Materials (1981) [ISIJ]

9 ) I. L. Dillamore: Texture. Cryst. Soli., 4 (1980), p. 41

10) J. L. WAlter and E. F. Косн: Acta Metall., 11 (1963), p. 923

11) $H$. Hu: Recovery and Recrystallization of Metals, ed. by L. Himmel (1963), p. 311 [Interscience]

12) I. L. Dillamore, P. L. Morris, C. J. E. Smith and $W$. B. Hutchinson: Proc. Roy. Soc., 329A (1972), p. 405

13）田岡忠美，古林英一，竹内 伸：鉄と鋼，54 (1968), p. 162

14) 古林英一: 鉄と鋼, 56 (1970), p. 734

15) $M$. Konishi, $T$. Obara, $T$. Tanaka and $N$. Ohashi: Proc. 5th Int. Conf. on Textures of Materials, ed. by $G$. Gotrstein and $K$. Lücke, II (1978), p. 255 [Springer-Verlag]

16) $W$. Boas and $M$. E. Hargreaves: Proc. Roy. Soc., 193A (1948), p. 89

17) 阿部光延, 小甲康二, 林 征夫, 速水哲博: 日本 金属学会誌, 44 (1980), p. 84

18) T. LEFFERs: 文献 20), p. 382

19) P. L. Morris: Thesis, Univ. Birmingham (1975)

20) $A$. $R$. Jones: Grain-Boundary Structure and Kinetics (1980), p. 379 [ASM]

21) $H$. Ahlborn and $D$. Sauer: Z. Metallkd., 59 (1968), p. 658

22) $J$. Grewen, $J$. Huber and M. Hatherly: Metals Forum, 1 (1978), p. 115

23) R. L. Aghan and J. Nutting: Met. Sci., 14 (1980), p. 233
24) $P . J$. Jackson and $D$. Kuhlmann-Wilsdorf: Scr. Metall., 16 (1982), p. 106

25) F. Adcock: J. Inst. Metals, 27 (1922), p. 73

26) $M$. Cook and $T$. L. Riahards: J. Inst. Met., $66(1940)$, p. $1 ; 69$ (1943), p. $351 ; 78$ (1950/ 51), p. 463

27) $P . S$. Mathur and $W . A$. Backofen: Metall. Trans., 4 (1973), p. 643

28) A. P. Davidson and D. R. F. West: Met. Sci., 13 (1979), p. 170

29) A. Dunn: Thesis, Univ. Liverpool (1968)

30) 稲垣裕輔：鉄と鋼, 62 (1976), p. 1000

31) $M$. Matsuo, $S$. Hayami and $S$. Nagashima: Proc. Int. Conf. Sci. Tech. Iron and Steel, Section 5 (1971), p. 867

32) $M$. Matsuo, $H$. Hayakawa and $S$. Hayami: 文献 15)，p. 275

33) 野田龍彦: 日本金属学会会報, 19 (1980), p. 638

34) G. I. TAYLOR: J. Inst. Met., 62 (1938), p. 307

35) $I$. L. Dillamore and $H$. Катон: Met. Sci., 8 (1974), p. 21, p. 73

36) 加藤 弘: 文献 2), p. 61

37) 加藤 弘: 博士論文, 京都大学 (1980)

38) 秋末 治: 日本金属学会誌, 40 (1976), p. 206

39) F. C. Frank: Plastic Deformation of Crystalline Solids (1950), p. 150 [Carnegie Inst. of Tech.]

40) J. C. M. Li: J. Austr. Inst. Met., 8 (1963), p. 206

41）五弓勇雄，松尾宗次：日本金属学会誌，31 (1967)，p. 374

42) D. Kuhlmann-Wilsdorf: J. Appl. Phys., 33 (1962), p. 648

43) D. Kuhlmann-Wilsdorf and E. Aernoudt: J. Appl. Phys., 54 (1983), p. 184

44) B. Grzemba and H. Hu: Z. Metallkd., 60 (1969), p. 944 